\title{
An Assessment of Environmental Impact on Glued Wood Building Elements
}

\section{Procjena utjecaja okolišnih uvjeta na lijepljene drvne elemente u graditeljstvu}

Original scientific paper • Izvorni znanstveni rad

Received-prispjelo: 7. 1. 2020.

Accepted-prihvaćeno: 14. 1. 2021.

UDK: $630 * 812.701 ; 630 * 812.751 ; 630 * 833.121$

https://doi.org/10.5552/drvind.2021.2001

(C) 2021 by the author(s).

Licensee Faculty of Forestry, University of Zagreb. This article is an open access article distributed under the terms and conditions of the Creative Commons Attribution (CC BY 4.0) license.

\begin{abstract}
The research investigated the impact of environmental factors (temperature and humidity) on pine glulam, oak glulam, and laminated veneer lumber ( $L V L)$ elements, all of which can be used in building structures. Elements underwent freezing, heating, drying, and wetting processes in different modes, thereby simulating different environmental conditions that could be encountered during the service period of the materials. Their mechanical properties (modulus of elasticity - MOE and coefficient of damping) were recorded at each stage. It was determined that, in the case of dry construction elements (where a moisture content was between 7.0 and $14.0 \%$ ), the MOE increases by a few percentage points with decreasing temperature and humidity levels, and decreases with increasing temperature and humidity levels. The coefficient of damping varied by $20 \%$ - in most cases, when the modulus of elasticity increased, this decreased, and vice versa. Under extreme environmental changes (with the elements being soaked, frozen at $-25^{\circ} \mathrm{C}$, and dried at $40^{\circ} \mathrm{C}$ ), the $\mathrm{MOE}$ of the glued timber decreased by $16 \%$ when this parameter of LVL decreased by about $10 \%$. Alterations in viscous properties produced similar results (the coefficient of damping increased by $50 \%$ for the glued timber and by $66 \%$ for the LVL). This is explained by the partial destruction of the element structure, the occurrence of cracks, and the decreased anisotropy of the LVL structure.
\end{abstract}

Keywords: glued wood (glulam); laminated veneer lumber; modulus of elasticity; coefficient of damping; wood defects

SAŽETAK • U radu je istraživan utjecaj okolišnih čimbenika (temperature $i$ vlage) na elemente lameliranih nosača izrađenih od borovine i hrastovine te na elemente lamelirane furnirske građe (LVL), koji se često rabe u graditeljstvu. Elementi su bili na različite načine podvrgnuti smrzavanju, zagrijavanju, sušenju $i$ vlaženju kako bi se simulirali različiti okolišni uvjeti koji bi se mogli pojaviti tijekom uporabe tih materijala. U svakoj su fazi ispitivanja bilježena mehanička svojstva promatranih drvnih elemenata (modul elastičnosti - MOE $i$ koeficijent prigušenja). Utvrđeno je da se u suhih građevinskih elemenata (sadržaj vode između 7,0 i 14,0\%) s padom temperature $i$ vlage MOE povećava za nekoliko postotnih bodova, a smanjuje se s porastom temperature $i$ vlage. Koeficijent prigušenja u većini je ispitivanja varirao za $20 \%$ : kako se modul elastičnosti povećavao, koeficijent prigušenja se smanjivao, i obrnuto. Pri ekstremnim promjenama okolišnih uvjeta (potapanjem elemenata, smrzavanjem na $-25{ }^{\circ} \mathrm{C}$ i sušenjem na $40{ }^{\circ} \mathrm{C}$ ) MOE lameliranih nosača se smanjio za $16 \%$, a LVL-a za oko $10 \%$. Glede promjena viskoelastičnih svojstava, zabilježeni su slični rezultati (koeficijent prigušenja lameliranih nosača povećao se za $50 \%$, a LVL-a za $66 \%$ ). To se objašnjava djelomičnom razgradnjom strukture drvnih elemenata, pojavom pukotina i smanjenom anizotropijom strukture LVL-a.

Ključne rïječi: lamelirani drvni nosači; lamelirana furnirska građa; modul elastičnosti; koeficijent prigušenja; greške drva

\footnotetext{
Author is associate professor at Kaunas University of Technology, Faculty of Mechanical Engineering and Design, Kaunas, Lithuania.

${ }^{2}$ Author is associate professor at Kaunas University of Technology, Faculty of Civil Engineering and Architecture, Kaunas, Lithuania.
} 


\section{INTRODUCTION}

\section{UVOD}

Timber and timber elements are widely used in building structures (Rindler et al., 2018; Sanscartier Pilon et al., 2019; Žlahtič-Zupanc et al., 2018; Risse et al., 2019; Subhani et al., 2017; Gilbert et al., 2017; Markström et al., 2018; Hildebrandt et al., 2017; Musselman et al., 2018). The production of various timber articles (laminated timber) has a purpose both in economic and ecological terms. In order to reduce emissions it is appropriate to use timber materials instead of concrete and steel structures. The demand for these materials is projected to continuously increase (Risse et al., 2019, Hildebrandt et al., 2017). The construction of buildings with more than two floors is one of the latest trends in which more timber products could be used (Markström et al., 2018).

Constructions that are made using glued timber materials, such as laminated veneer lumber (LVL) and cross laminated timber (CLT), can be used to reinforce concrete and steel structures and ensure better protection levels against earthquakes (Sanscartier Pilon et al., 2019).

More lately, identifying, improving, and forecasting the properties of timber structures has become a topical subject. It is already known that, in most cases, timber becomes wet or dry when in service under the changing ambient temperature and humidity levels. Alterations in timber moisture content may result in alterations in terms of dimensions and shape of timber materials, or the occurrence of various defects and changes in mechanical properties (Wood Handbook, 2010). It has already been established that an increase in temperature from $-30{ }^{\circ} \mathrm{C}$ to $+30{ }^{\circ} \mathrm{C}$ will decrease the $M O E$ in timber materials (Ayrilmis et al., 2010).

The impact of different factors on alterations in the moisture content of timber materials under ambient conditions was also something that has previously been investigated. The absorption properties of timber materials can be altered by applying thermal modifications, along with wax, oil, and biocide treatments (Žlahtič-Zupanc et al., 2018). It has been determined that the moisture content of glued timber materials which changes under the influence of the ambient temperature - also alters its mechanical properties. In addition, the change in these properties also depends on the glue that has been used (Rindler et al., 2018). The mechanical properties of one of the most commonly used construction materials - LVL - can be improved by using other materials, such as polymeric options (Subhani et al., 2017). Thanks to the digital model developed, it is possible to predict the LVL mechanical properties in various directions and to produce beams of the desired mechanical properties (Gilbert et al., 2017). Building structures often require holes to be made in the materials. It has been determined that both the diameter of those holes and, especially, their location affect the strength properties and durability of LVL beams (Musselman et al., 2018).

The aim of the study is to evaluate the impact of environment factors on the mechanical properties of glulam beams in both oak and pine, as well as LVL beams.

\section{MATERIALS AND METHODS} 2. MATERIJALI I METODE

The research study used glued oak and pine glulam beams (each glued segment consisting of five planks) and LVL beams (the thickness of the layer was about $3 \mathrm{~mm}$ ) with the dimensions of $1200 \mathrm{~mm} \times 75$ $\mathrm{mm} \times 100 \mathrm{~mm}$, a humidity level was between 10.5-14.0 $\%$, and the density was accordingly within the limits of $740-780 \mathrm{~kg} / \mathrm{m}^{3}, 520-550 \mathrm{~kg} / \mathrm{m}^{3}$, and $590-670 \mathrm{~kg} / \mathrm{m}^{3}$, respectively. The glulam beams were glued by using water-resistant polyurethane glues, and the LVL specimens were glued by using formaldehyde-based glues. There were 10 beams of each type. A schematic for specimen cross-sections is provided in Figure 1.

In order to simulate changes in environmental parameters, the climatic conditions were modelled in the climatic chamber (the appropriate air temperature and relative humidity are determined in the chamber, all samples are stacked in chamber and the change in their mechanical properties is recorded every 7 days). In the chamber, the temperature was maintained within an accuracy level of $1{ }^{\circ} \mathrm{C}$, and the relative humidity level was maintained within an accuracy level of $2 \%$. The length of the specimens was measured using a tape measure within an accuracy of $1 \mathrm{~mm}$, while the width and thickness were measured using sliding callipers within an accuracy of $0.05 \mathrm{~mm}$, and the mass was measured using a balance within an accuracy of $0.1 \mathrm{~g}$. The moisture content for the specimens was measured with an electric resistance moisture meter.

4 cycles were simulated: "cold" - samples frozen in air at $-25^{\circ} \mathrm{C}$, "dry" - samples kept at $40{ }^{\circ} \mathrm{C}$ at $40 \%$ relative humidity, "wet" - samples irrigated at $20{ }^{\circ} \mathrm{C}$ at $85 \%$ humidity and "extreme" - the samples were soaked in water at $20{ }^{\circ} \mathrm{C}$, frozen in air at $-25{ }^{\circ} \mathrm{C}$ and dried at $40{ }^{\circ} \mathrm{C}$ and $40 \%$ relative humidity.

Before carrying out the research study, all specimens were conditioned in a climatic chamber for a total of fourteen days at $20{ }^{\circ} \mathrm{C}$ and with a relative air

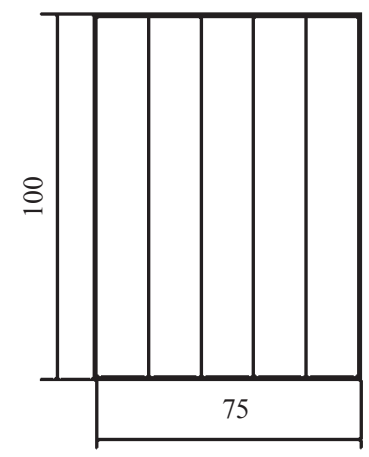

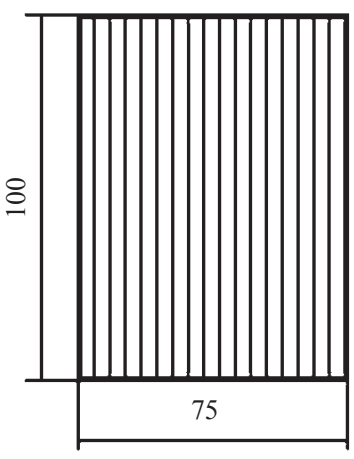

Figure 1 A schematic of specimen cross-sections: a) oak and pine glulam beams; b) LVL beams

Slika 1. Shema poprečnog presjeka uzoraka: a) lamelirani nosači od hrastovine i borovine; b) nosači od lamelirane furnirske građe 


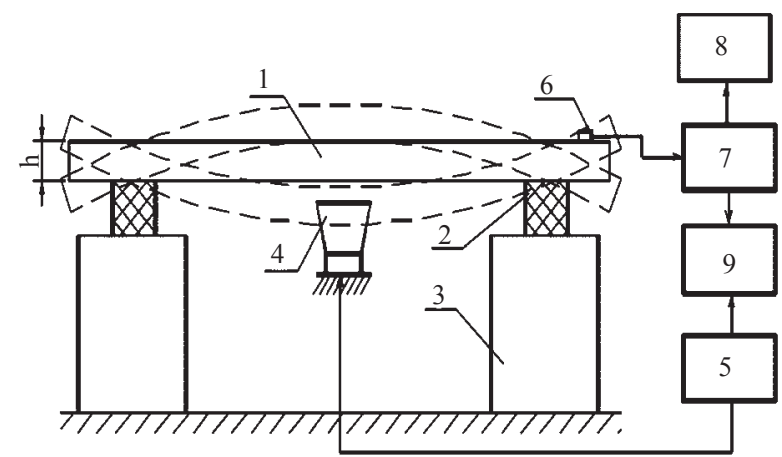

Figure 2 Scheme of the test stand: 1 - specimen; 2 - vibration damping material (foam rubber); 3 - massive supports; 4 loudspeaker; 5 - vibration generator; 6 - sensor; 7 - measuring instrument; 8 - oscilloscope; 9 - phase meter

Slika 2. Shema ispitnog postolja: 1 - uzorak; 2 - materijal za prigušivanje vibracija (spužvasta guma); 3 - masivni nosači; 4 - zvučnik; 5 - generator vibracija; 6 - senzor; 7 - mjerni uređaj; 8 - osciloskop; 9 - mjerač faze

humidity of $60 \%$. After completing the conditioning process, the moisture content of the specimens was measured at between 11.0-12.5\%.

The special test stand (Figure 2) was used to determine the $M O E$ and the coefficient of damping on the basis of the non-destructive testing (transverse resonant vibrations) method, which also allowed assessing the mechanical properties of the specimens (Albrektas and Vobolis, 2003; Albrektas and Vobolis, 2004; Timoshenko et al., 1985). The studies were performed at a frequency of 20-2000 Hz.

The $M O E$ was calculated based on the following Eq. 1 (Timoshenko et al., 1985):

$$
E=\frac{f_{\mathrm{rez}}^{2} \cdot 4 \cdot \pi^{2} \cdot \rho \cdot s \cdot l^{4}}{I \cdot A^{2}}
$$

Where: $E$-modulus of elasticity, $f_{\text {rez }}-$ frequency of transverse vibrations, $\rho$-density of wood, $s$ - crosssectional area, $l$ - beam length, $I$ - cross-sectional moment of inertia, $A$ - method of fastening represented by a coefficient

The viscous properties of studied specimens were evaluated based on the following Eq. 2

$$
\operatorname{tg} \delta \approx \frac{\Delta f}{f_{\text {rez }}}
$$

Where: $f_{\text {rez }}$ - frequency of transverse vibrations, $\Delta f$ - frequency bandwidth when amplitude of vibrations decreases by 0.7 times.

The $M O E$ and the coefficient of damping for each specimen were determined in two directions: with the glue joints on the specimens orientated as shown in Figure 1 and the specimen turned at an angle of $90^{\circ}$.
For example, the oak glulam beam that falls within code 'O1', should be coded 'O1.1' when placed on a test stand as shown in Figure 1, and 'O1.2' when turned at an angle of $90^{\circ}$. The average values for all ten oak timber beams are marked as 'OX.1' and 'OX.2', respectively. Meanwhile, the groups into which the pine glulam beams have been organised are marked as 'PX.1' and 'PX.2', respectively, and the LVL specimens are marked as 'LX.1' and 'LX.2', respectively.

\section{RESULTS AND DISCUSSION}

\section{REZULTATI I RASPRAVA}

The measurements for the $M O E$ and the coefficient of damping for the specimens was carried out after completing the conditioning process. These values are displayed in Table 1.

It was estimated that the $M O E$ of oak glulam beams altered within the limits of 11500-14200 MPa, and for pine glulam beams it was within the limits of 11000-13400 MPa, while the LVL altered within the limits of 12900-14900 MPa. The coefficient of damping for all specimens remained within the limits of 0.0085-0.0145 r.u. These values correspond to the values that are given in the available literature (Albrektas and Vobolis, 2003; Wagenführ, 2000; Wood Handbook, 2010; Albrektas et al., 2019).

It should be noted that the $M O E$ of the LVL specimens is slightly higher, although it corresponds to the $M O E$ of natural wood. In addition, having carried out a statistical analysis of the $M O E$ and coefficient of damping values for each group, it was found that the coefficient of variation for the $M O E$ values in the LVL specimens was approximately $2 \%$, and the coefficient of variation of the coefficient of damping was approximately $5 \%$. These coefficients of variation for oak and pine specimens altered within the limits of $6-8 \%$.

In order to simulate the various operating conditions of their structures, the specimens underwent a freezing phase at $-25^{\circ} \mathrm{C}$ and were observed for changes in their mechanical properties. Variations in the $M O E$ are displayed in Figure 3.

The results show that, during a freezing phase, the $M O E$ increased for all specimens. The most significant increase was recorded after the first seven days. For the oak specimens the increase amounted to $1.5 \%$, for the pine specimens it was $4.9 \%$, and for the LVL specimens it was $5.5 \%$. After a period of 21 days, the $M O E$ for the oak specimens increased by $3.1 \%$, for the pine specimens by $5.5 \%$, and for the LVL by $6.6 \%$ in comparison to the original value. In all cases the increase in the $M O E$ for group ' 1 ' is higher than that of

Table 1 Average values for $M O E$ and coefficient of damping for specimens

Tablica 1. Srednje vrijednosti $M O E$-a i koeficijenta prigušenja za ispitivane uzorke

\begin{tabular}{|c|c|c|c|c|c|c|}
\hline $\begin{array}{c}\text { Group of } \\
\text { specimens } \\
\text { Grupa }\end{array}$ & \multicolumn{2}{|c|}{ Oak / Hrastovina } & \multicolumn{2}{c|}{ Pine / Borovina } & \multicolumn{2}{c|}{ LVL } \\
\cline { 2 - 7 } $\begin{array}{c}\text { uzoraka } \\
\text { MOE, }\end{array}$ & $\begin{array}{c}\text { Coef. of damping, r.u. } \\
\text { Koeficijent prigušenja, r.u. }\end{array}$ & $\begin{array}{c}\text { MOE, } \\
\mathrm{MPa}\end{array}$ & $\begin{array}{c}\text { Coef. of damping, r.u. } \\
\text { Koeficijent prigušenja, r.u. }\end{array}$ & $\begin{array}{c}\text { MOE, } \\
\text { MPa }\end{array}$ & $\begin{array}{c}\text { Coef. of damping, r.u. } \\
\text { Koeficijent prigušenja, r.u. }\end{array}$ \\
\hline $\mathrm{X} 1$ & 12420 & 0.0100 & 11530 & 0.0115 & 14510 & 0.0113 \\
\hline $\mathrm{X} 2$ & 13470 & 0.0121 & 12110 & 0.0110 & 13160 & 0.0118 \\
\hline
\end{tabular}




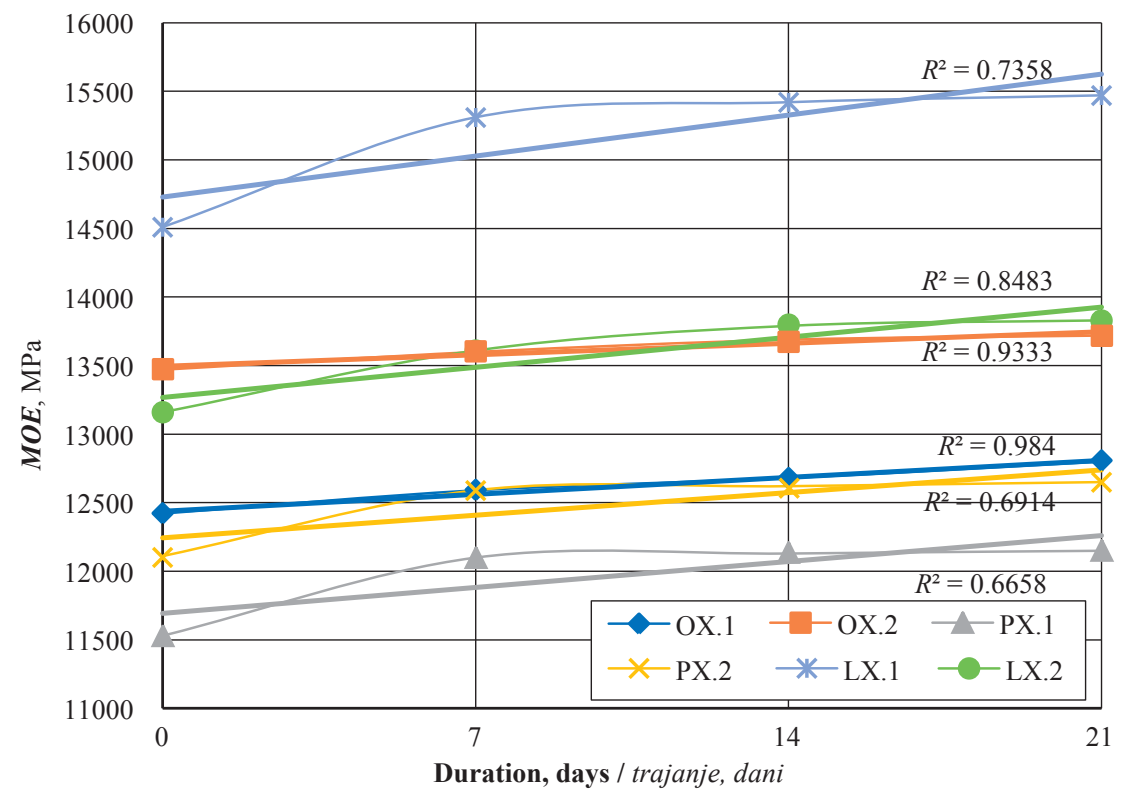

Figure 3 Variations of $M O E$ in specimens during a freezing phase Slika 3. Varijacije $M O E$-a na uzorcima tijekom faze smrzavanja

group ' 2 '. This can be explained by the fact that, just as with the timber, the glue becomes stiffer at lower temperatures and, with its existing orientation, the influence of glue on the entire composite is greater, although its $M O E$ is significantly lower (Konnerth et al., 2006; Stoeckel et al., 2013). Similar results were obtained for other glued timber materials (Ayrilmis et al., 2010).

The viscous properties of the specimens also altered during the freezing phase. The variations in the coefficient of damping are shown in Figure 4.

It is clear that the coefficient of damping for all specimens tended to decrease during the freezing phase, i.e. the specimens lost plasticity. The most significant decrease was recorded after the first seven days. The most significant decrease in the coefficient of damping was observed in pine specimens (with an average decrease of $17.4 \%$ ), while the least significant decrease was observed in the LVL specimens (at an average of $7.1 \%$ ). During further freezing, the coefficient of damping decreased less. For pine specimens, it decreased by an average of $20.0 \%$, for oak specimens by an average of $16.5 \%$, and for the LVL specimens by an average of $10.6 \%$. Unlike the $M O E$, the coefficient of damping in oak and pine specimens was particularly unaffected by the orientation of the glue joint. For the LVL specimens alone, the average coefficient of damping of group ' 1 ' specimens decreased by $10.6 \%$, and by $5.1 \%$ for the specimens in group ' 2 '.

Afterwards, the specimens underwent a drying phase at $40{ }^{\circ} \mathrm{C}$, at $40 \%$ relative air humidity, and with about $1 \mathrm{~m} / \mathrm{s}$ forced circulation. During the drying process, the mass of the specimens decreased by between

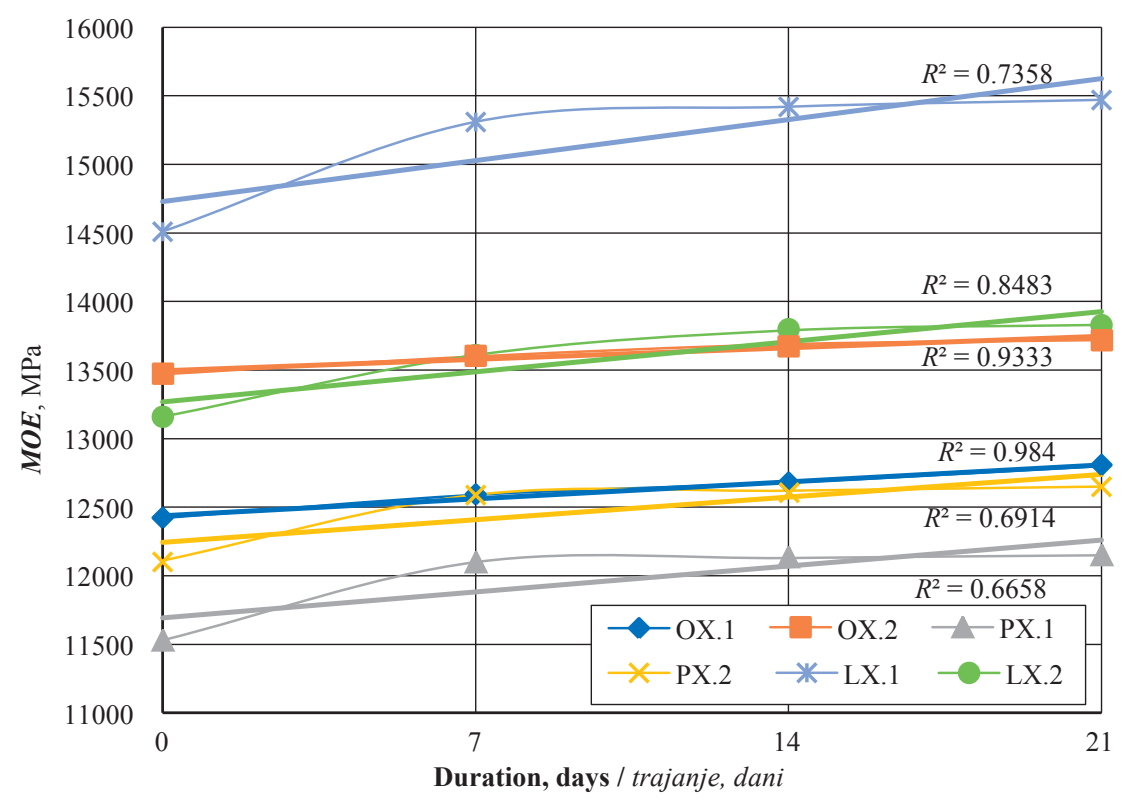

Figure 4 Variations in coefficient of damping for specimens during the freezing phase

Slika 4. Varijacije koeficijenta prigušenja na uzorcima tijekom faze smrzavanja 
... Albrektas, Ivanauskas: An Assessment of Environmental Impact on Glued Wood Building...

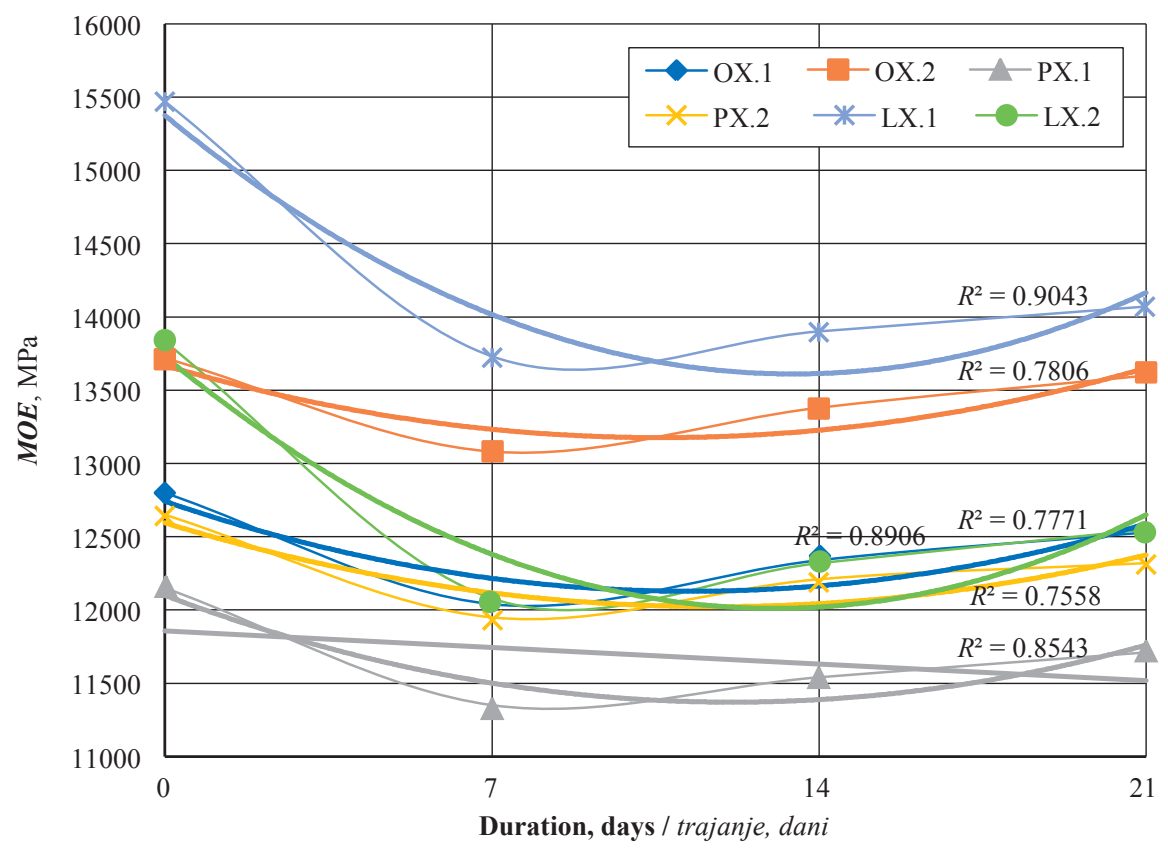

Figure 5 Variations in $M O E$ for specimens during the drying phase

Slika 5. Varijacije $M O E$-a na uzorcima tijekom faze sušenja

54-98 g per week. The variations in the $M O E$ for the specimens are shown in Figure 5.

It was established that, at the beginning of the drying phase (after the first seven days), the $M O E$ for the specimens decreased (by $5.9 \%$ for oak specimens, 6.6 $\%$ for pine specimens, and $12.7 \%$ for LVL specimens). This could be explained by the fact that the moisture content decreased by an insignificant level during the first seven days (the specimen mass decreased on average by about $52 \mathrm{~g}$ and the average moisture content decreased by about 1.0-1.2\%); however, the timber warmed up and became more flexible. Later, during the drying process, the mass of the specimen decreased, and the $M O E$ increased at a similar rate. When compared to the $M O E$ of the frozen specimens before drying, after a period of 21 days the average $M O E$ for the oak specimens decreased by $2.1 \%$, for the pine specimens by 3.6 $\%$, while the LVL specimens decreased by $9.3 \%$. In this case the orientation of the glue joint did not have any significant impact (the difference did not exceed $1 \%$ ).

The variation in the coefficient of damping during the drying process is shown in Figure 6.

The results show that, after the first seven days of drying, the coefficient of damping for all specimens increased (by $13 \%$ for the pine and the LVL specimens, and by $9 \%$ for the oak specimens); this was due to the

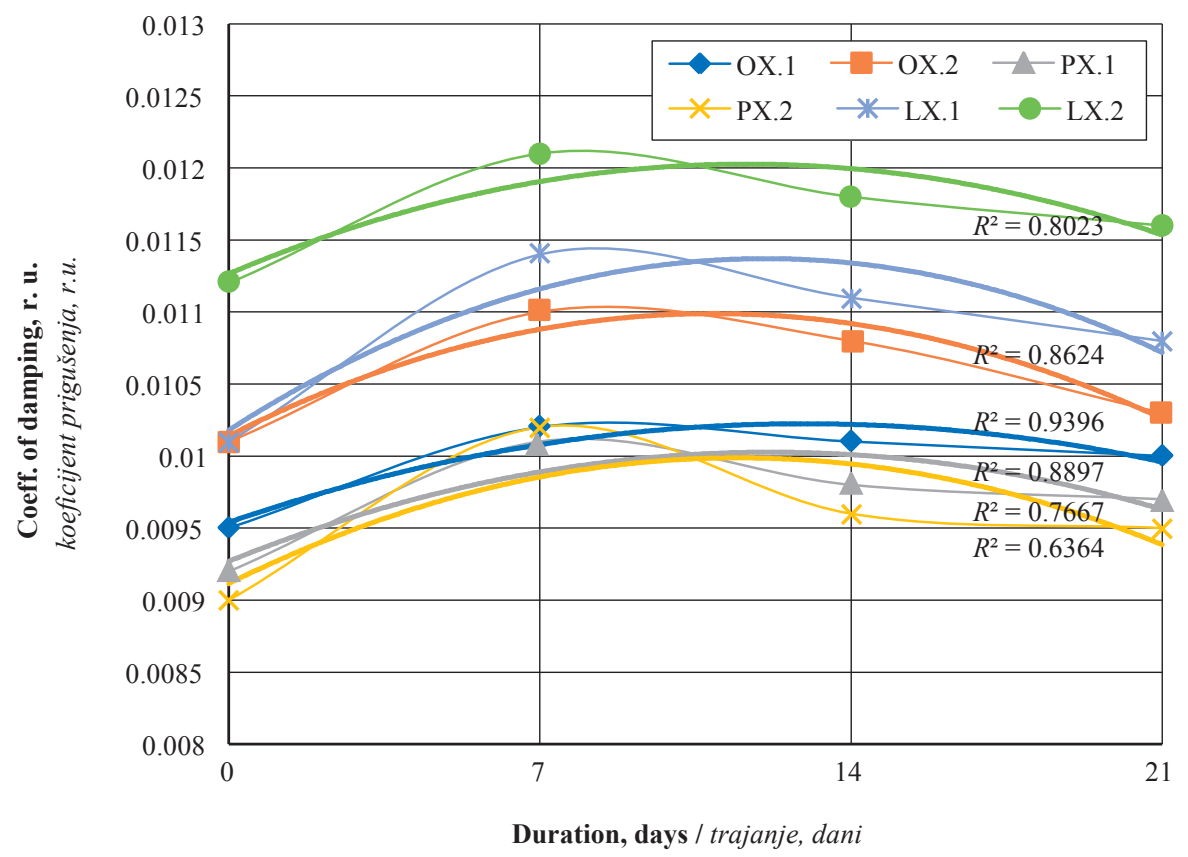

Figure 6 Variation in coefficient of damping for specimens during the drying process

Slika 6. Varijacije koeficijenta prigušenja na uzorcima tijekom faze sušenja 


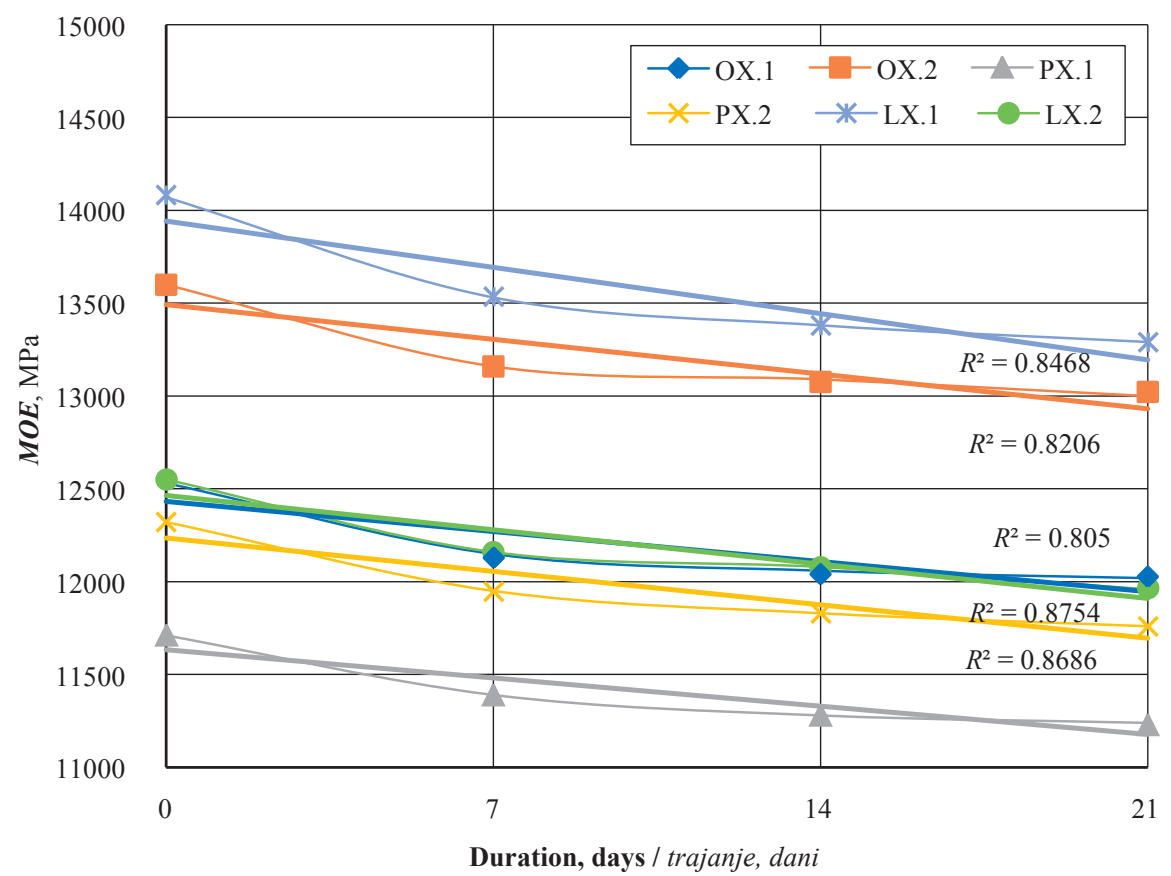

Figure 7 Variation in $M O E$ of specimens during the wetting process

Slika 7. Varijacije $M O E$-a na uzorcima tijekom faze vlaženja

fact that the timber warmed up and became more flexible. During further drying, the coefficient of damping decreased by an insignificant amount. When compared to the primary coefficient of damping (after freezing), the coefficient of damping for all specimens, which were dried for 21 days, managed to increase by between $2.0-6.9 \%$.

The specimens were dampened in a climate chamber at $20^{\circ} \mathrm{C}$ and at a relative air humidity of $85 \%$. The variation in the $M O E$ during the wetting process is shown in Figure 7.

It was found that the $M O E$ for all specimens decreased by an insignificant amount during the wetting process. The greatest decrease in the $M O E$ was observed in the LX.1 specimen group (by an average of $3.8 \%$ during the first seven days and by an average of $5.5 \%$ during a period of 21 days). Variations for other groups of specimens were found to be $3.0 \%$ and between 4.0 $4.7 \%$, respectively. The differences are very small (the mass of the specimens pretty much increased in an identical manner); therefore it can be stated that the humid air had an equal effect on the elastic properties of all of the specimens. The variations in viscous properties (the coefficient of damping) are shown in Figure 8.

It was established that the coefficient of damping for the specimens increased during the wetting process.

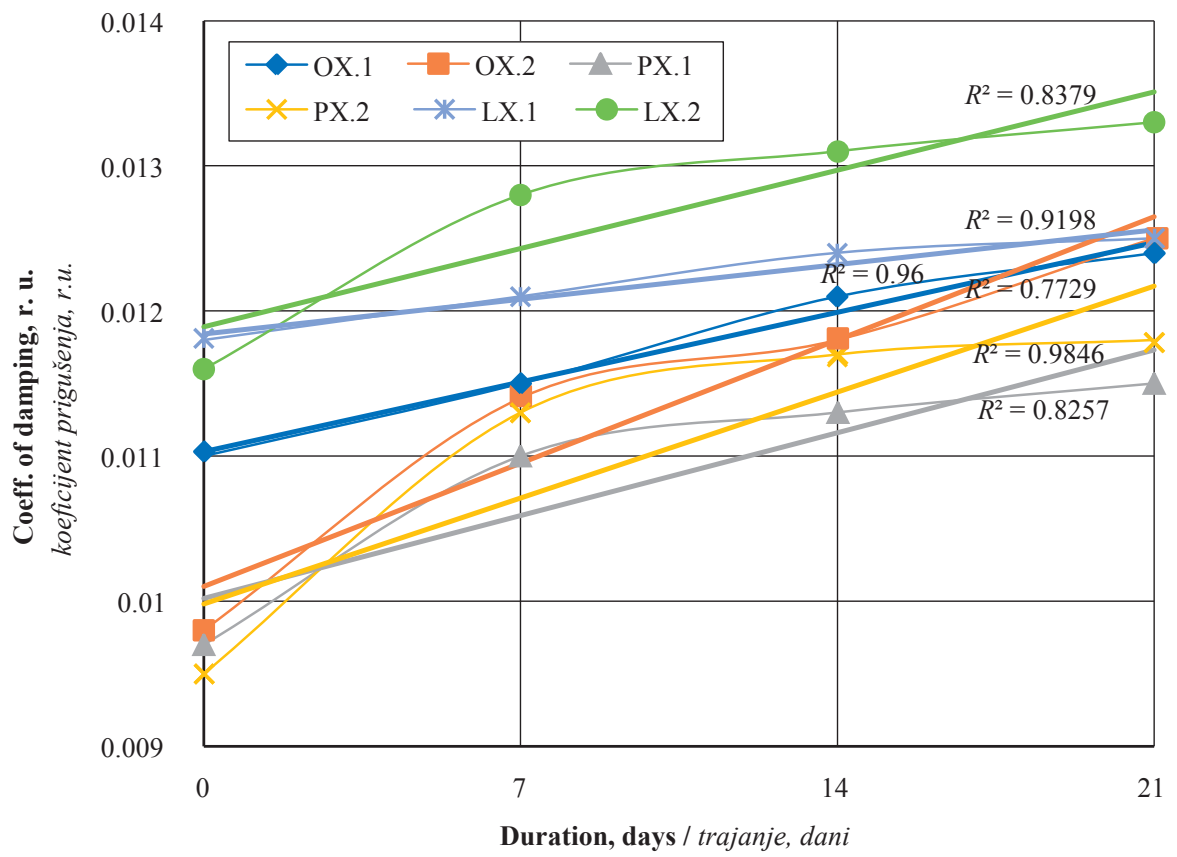

Figure 8 Variations in coefficient of damping for specimens during the wetting process

Slika 8. Varijacije koeficijenta prigušenja na uzorcima tijekom faze vlaženja 
The highest growth levels were observed during the first seven days (for all groups of specimens the coefficient of damping increased by between 10-19\%). The lowest growth in coefficient of damping after 21 days was observed for the LVL specimens (14.7\% and $15.7 \%$, respectively, for individual groups). The average growth of the coefficient of damping in the oak specimens was at $21.4 \%$ and $24.0 \%$, respectively, whereas the coefficient of damping for the pine specimens was at $18.6 \%$ and $24.2 \%$. It is likely that the slightly different behaviour of the LVL specimens was prompted by the relatively large number of glue joints, which ensured a more uniform structure in the entire specimen.

The specimens were then immersed in water at a temperature of $20^{\circ} \mathrm{C}$ and were then stored for a period of fourteen days; then they were removed from the water and stored at $-25^{\circ} \mathrm{C}$ for fourteen days; subsequently they were dried at $40{ }^{\circ} \mathrm{C}$ for fourteen days with a relative air humidity of $40 \%$ and forced air circulation. This was done in order to intentionally cause defects in the specimens.

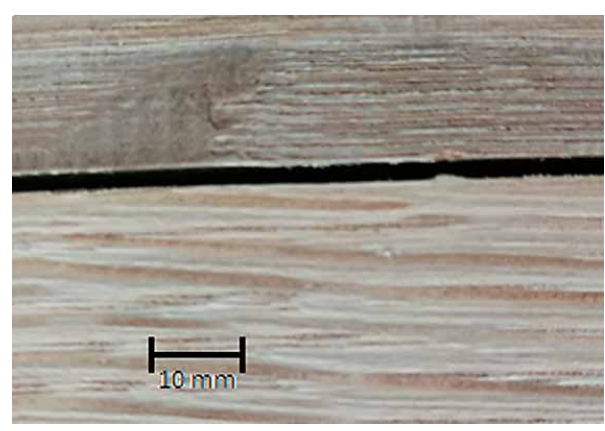

a

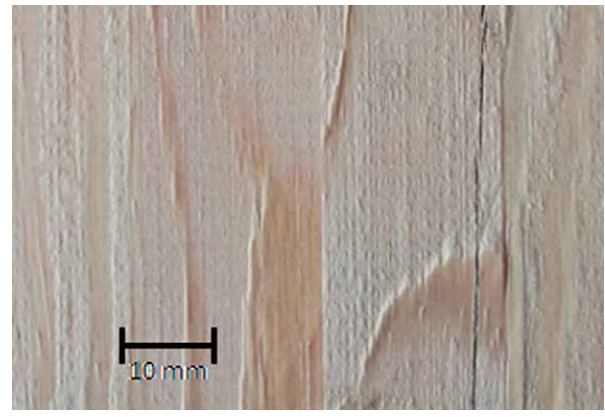

c

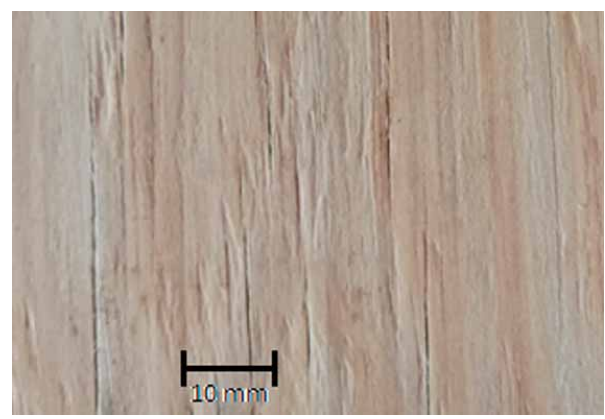

e
Pictures of several specimens after the immersion/freezing/drying process are shown in Figure 9.

It is evident that the drastic environmental impact in most cases caused a serious level of damage to the glulam specimens tested. Clearly-visible cracks emerged when exposed to sources of tension. Visually significant defects were not observed in the LVL specimens. In most cases there were shallow cracks (singlelayer thickness) that became visible on the face. Small peelings on the cross section were also observed.

Table 2 shows the values for the mechanical properties of the specimens following the conditioning process (initial) and after the immersion/freezing/drying process (final).

It was established that the extreme humidity and temperature fluctuations had a significant impact on the specimens. The results show that the cracks that appeared resulted in a decrease in the $M O E$ of glulam beams by between 13-16 \%, while for the LVL specimens this value was a little lower at around $10 \%$. However, the coefficient of damping for the specimens changed much more significantly. The uniform struc-

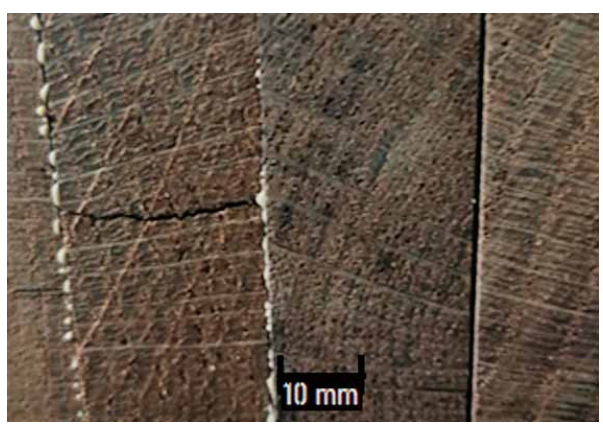

b

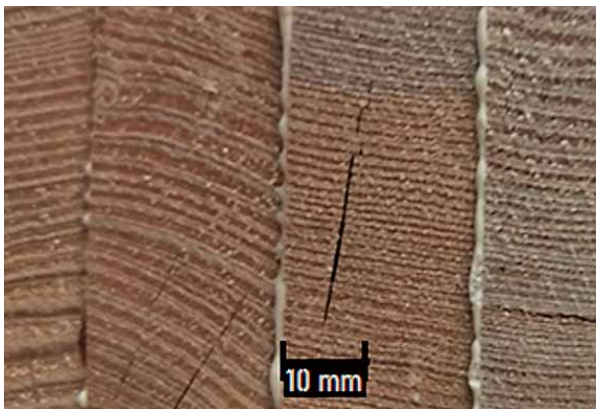

d

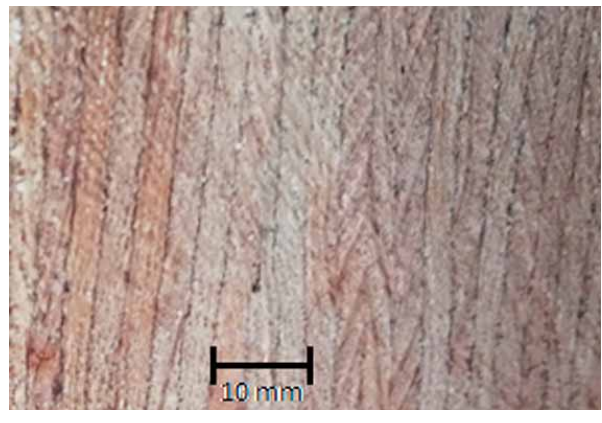

f

Figure 9 Examples of typical defects in specimens: a) face of oak specimen; b) cross section of oak specimen; c) face of pine specimen; d) cross section of pine specimen; e) face of LVL specimen; and f) cross section of LVL specimen Slika 9. Primjeri tipičnih grešaka na uzorcima: a) lice uzoraka hrastovine; b) poprečni presjek uzoraka hrastovine; c) lice uzoraka borovine; d) poprečni presjek uzoraka borovine; e) lice LVL uzoraka; f) poprečni presjek LVL uzoraka 
Table 2 Changes in mechanical properties after immersion/freezing/drying process

Tablica 2. Promjene mehaničkih svojstava nakon procesa potapanja, smrzavanja i sušenja

\begin{tabular}{|c|c|c|c|c|c|c|c|c|}
\hline \multirow{2}{*}{$\begin{array}{l}\text { Group } \\
\text { Grupe }\end{array}$} & \multicolumn{2}{|c|}{ MOE, $\mathrm{MPa}$} & \multirow{2}{*}{\multicolumn{2}{|c|}{$\begin{array}{c}\text { Difference, } \mathrm{MPa} / \% \\
\text { Razlika, } \mathrm{MPa} / \%\end{array}$}} & \multicolumn{2}{|c|}{$\begin{array}{l}\text { Coefficient of damping, r.u. } \\
\text { Koeficijent prigušenja, r.u. }\end{array}$} & \multirow{2}{*}{\multicolumn{2}{|c|}{$\begin{array}{c}\text { Difference, r.u. } / \% \\
\text { Razlika, r.u. } \% \%\end{array}$}} \\
\hline & Initial / Početno & Final / Završno & & & Initial /Početno & Final / Završno & & \\
\hline OX.1 & 12420 & 10510 & 1910 & 15.4 & 0.0110 & 0.0168 & 0.0058 & 52.7 \\
\hline OX.2 & 13470 & 11680 & 1790 & 13.3 & 0.0121 & 0.0179 & 0.0058 & 47.9 \\
\hline PX.1 & 11530 & 9980 & 1550 & 13.4 & 0.0115 & 0.0173 & 0.0058 & 50.4 \\
\hline PX.2 & 12110 & 10350 & 1760 & 14.5 & 0.0110 & 0.0167 & 0.0057 & 51.8 \\
\hline LX.1 & 14510 & 13030 & 1480 & 10.2 & 0.0113 & 0.0185 & 0.0072 & 63.7 \\
\hline LX.2 & 13160 & 11790 & 1370 & 10.4 & 0.0118 & 0.0196 & 0.0078 & 66.1 \\
\hline
\end{tabular}

ture of the specimens was destroyed, causing the specimen that underwent vibration treatment to behave like a system involving several bodies rather than as a single body. The coefficient of damping for the natural timber specimens increased by about $50 \%$ and the one for the LVL specimens increased even more.

All of the results were statistically processed. The coefficient of variation for the $M O E$ and the coefficient of damping for different groups after each test cycle did not exceed $9.6 \%$ (Pekarskas, 2007).

\section{CONCLUSIONS}

\section{ZAKLJUČAK}

It was established that, due to different mechanical properties of timber in different directions (perpendicular and parallel to the positioning directions of the joints), the same glulam beam had different mechanical properties. This difference for individual glulam beams was up to $4.8 \%$.

During freezing process, the dry glulam beams (at between 11.0-12.5\%) become more elastic. This is shown by the $M O E$ which increased by $6.6 \%$ and by the coefficient of damping which decreased by $20.0 \%$.

After starting the drying process in frozen specimens, during the first seven days their moisture content decreased by an insignificant amount (by $1.2 \%$ ). However, the timber warmed up and became more flexible. Therefore, during the period of seven days of drying, the $M O E$ decreased by $12.7 \%$, whereas the coefficient of damping increased by $13.0 \%$.

As the moisture content of glulam beams decreases, its $M O E$ increases and the coefficient of damping decreases (with a moisture content reduction of about $3 \%$ the $M O E$ increased by an average of between 2.8-3.2\%, whereas the coefficient of damping decreased by between 2.3-8.5\%).

During the process of wetting, glulam specimens in the air had a moisture content that increased by an average of between 3.0-4.0\%, while their $M O E$ decreased by $5.5 \%$, and the coefficient of damping increased by $24.2 \%$. This is mainly due to the increase in surface humidity and plasticity.

Coefficient of damping for the LVL specimens increased the least only during the wetting process (on average by $15.7 \%$ ). It is likely that the slightly different behaviour of the LVL specimens was prompted by the relatively large number of glue joints, which ensured a more uniform structure in the entire specimen.

Freezing wet glulam specimens and their subsequent drying (which served to cause the defects) showed the lowest levels of deterioration in LVL elastic properties (by an average of $10.4 \%$ ); however, the viscous properties increased significantly (the coefficient of damping increased by $66.1 \%$ ).

In general it can be stated that the glulam beams and the LVL beams reacted similarly to changing environmental conditions.

\section{REFERENCES}

\section{LITERATURA}

1. Ayrilmis, N.; Buyuksari, U.; As, N., 2010: Bending strength and modulus of elasticity of wood-based panels at cold and moderate temperatures. Cold Regions Science and Technology, 63: 40-43.

https://doi.org/10.1016/j.coldregions.2010.05.004.

2. Albrektas, D.; Vobolis, J., 2003: Investigation of mechanical parameters and defects of solid wood glued panels. Materials science. Kaunas University of Technology, Academy of Sciences of Lithuania, 9 (4): 368-373.

3. Albrektas, D.; Vobolis, J., 2004: Modelling and study of glued wood panel. Materials science. Kaunas University of Technology, Academy of Sciences of Lithuania, Kaunas. Technologija, 10 (4): 370-373.

4. Albrektas, D.; Revuckaite, E.; Dobilaitè, V.; Jucienė, M., 2019: Influence of finishing materials on viscous elastic properties of wooden structures. Drvna industrija, 70 (1): 89-94. https://doi.org/10.5552/drvind.2019.1816.

5. Gilbert, B. P.; Bailleres, H.; Zhang, H.; McGavin, R. L., 2017: Strength modelling of Laminated Veneer Lumber (LVL) beams. Construction and Building Materials, 149: 763-777.

https://doi.org/10.1016/j.conbuildmat.2017.05.153.

6. Hildebrandt, J.; Hagemann, N.; Thrän, D., 2017: The contribution of wood-based construction materials for leveraging a low carbon building sector in Europe. Sustainable Cities and Society, 34: 405-418.

https://doi.org/10.1016/j.scs.2017.06.013.

7. Konnerth, J.; Gindl, W.; Muller, U., 2006: Elastic properties of adhesive polymers. I. Polymer films by means of electronic speckle pattern interferometry. Wiley InterScience. https://doi.org/10.1002/app.24434.

8. Markström, E.; Kitek Kuzman, M.; Bystedt, A.; Sandberg, D.; Fredriksson, M., 2018: Swedish architects view of engineered wood products in buildings. Journal of Cleaner Production, 181: 33-41.

https://doi.org/10.1016/j.jclepro.2018.01.216. 
... Albrektas, Ivanauskas: An Assessment of Environmental Impact on Glued Wood Building...

9. Musselman, E. S.; Dinehart, D. W.; Walker, S. M.; Mancini, M. L., 2018: The effect of holes on the creep behavior and flexural capacity of laminated veneer lumber (LVL) beams. Construction and Building Materials, 180: 167-176. https://doi.org/10.1016/j.conbuildmat.2018.05.186.

10. Pekarskas, V., 2007: Matematinè inžinerinio eksperimento teorija (Mathematical theory of engineering experiment). Šiauliai. Šiauliai University Press (in Lithuanian): pp. 180.

11. Rindler, A.; Pöll, C.; Hansmann, C.; Müller, U.; Konnerth, J., 2018: Moisture related elastic and viscoelastic behaviour of wood adhesives by means of in-situ nanoindentation. International Journal of Adhesion and Adhesives, 85: 123-129.

https://doi.org/10.1016/j.ijadhadh.2018.06.004.

12. Risse, M.; Weber-Blaschke, G.; Richter, K., 2019: Ecoefficiency analysis of recycling recovered solid wood from construction into laminated timber products. Science of The Total Environment, 661: 107-119. https://doi.org/10.1016/j.scitotenv.2019.01.117.

13. Sanscartier Pilon, D.; Palermo, A.; Sarti, F.; Salenikovich, A., 2019: Benefits of multiple rocking segments for CLT and LVL Pres-Lam wall systems. Soil Dynamics and Earthquake Engineering, 117: 234-244. https://doi.org/10.1016/j.soildyn.2018.11.026.

14. Stoeckel, F.; Konnerth, J.; Gindl-Altmutter, W., 2013: Mechanical properties of adhesives for bonding wood A review. International Journal of Adhesion and Adhesives, 45: 32-41.

https://doi.org/10.1016/j.ijadhadh.2013.03.013.
15. Subhani, M.; Globa, A.; Al-Ameri, R.; Moloney J., 2017: Flexural strengthening of LVL beam using CFRP. Construction and Building Materials, 150: 480-489. https://doi.org/10.1016/j.conbuildmat.2017.06.027.

16. Timoshenko, S. P.; Young, D. H.; Weaver, W. Jr., 1985: Vibration problems in engineering. Moscow. Mashinostroenie, 472.

17. Wagenführ, R., 2000: Holzatlas: mit zahlreichen Abbildungen München: Fachbuchverlag Leipzig im Carl Hanser Verlag: 707.

18. Wood Handbook, 2010: Wood as an Engineering Material. Centennial Edition. Forest Products Laboratory. Wood handbook - Wood as an engineering material. General Technical Report FPL-GTR-190. Madison, WI: U.S. Department of Agriculture, Forest Service, Forest Products Laboratory: 508.

19. Žlahtič-Zupanc, M.; Lesar, B.; Humar, M., 2018: Changes in moisture performance of wood after weathering. Construction and Building Materials, 193: 529-538. https://doi.org/10.1016/j.conbuildmat.2018.10.196.

\section{Corresponding address:}

Assoc. prof. dr. DARIUS ALBREKTAS

Kaunas University of Technology

Faculty of Mechanical Engineering and Design Studentu st. 56, LT - 51424 Kaunas, LITHUANIA e-mail: Darius.Albrektas@ktu.lt 